\title{
ROOT PHOSPHATASE ACTIVITY, PLANT GROWTH AND PHOSPHORUS ACCUMULATION OF MAIZE GENOTYPES
}

\author{
Cynthia Torres de Toledo Machado ${ }^{1}$; Ângela Maria Cangiani Furlani²* \\ ${ }^{1}$ Embrapa Cerrados, C.P. 08223 - 73301-970 - Planaltina, DF - Brasil. \\ ${ }^{2}$ Instituto Agronômico, Centro de Pesquisa e Desenvolvimento de Solos e Recursos Ambientais, C.P. 28 - \\ 13001-970 - Campinas, SP - Brasil. \\ *Corresponding author 〈afurlani@iac.sp.gov.br>
}

\begin{abstract}
The activity of the enzyme phosphatase (P-ase) is a physiological characteristic related to plant efficiency in relation to $\mathrm{P}$ acquisition and utilization, and is genetically variable. As part of a study on maize genotype characterization in relation to phosphorus $(\mathrm{P})$ uptake and utilization efficiency, two experiments were set up to measure phosphatase (P-ase) activity in intact roots of six local and improved maize varieties and two sub-populations. Plants were grown at one P level in nutrient solution $\left(4 \mathrm{mg} \mathrm{L}^{-1}\right)$ and the P-ase activity assay was run using 17-day-old plants for varieties and 24-day-old plants for subpopulations. Shoot and root dry matter yields and $\mathrm{P}$ concentrations and contents in plant parts were determined, as well as P-efficiency indexes. Root P-ase activity differed among varieties, and highest enzimatic activities were observed in two local varieties - 'Catetão' and 'Caiano' - and three improved varieties - 'Sol da Manhã', 'Nitrodente' and 'BR 106'. 'Carioca', a local variety, had the lowest activity. Between subpopulations, ' $\mathrm{ND}_{2}$ ', with low yielding and poorly P-efficient plants, presented higher root P-ase activity as compared to ' $\mathrm{ND}_{10}$ ', high yielding and highly P-efficient plants. In general, subpopulations presented lower P-ase activities as compared to varieties. Positive and/or negative correlations were obtained between P-ase activity and P-efficiency characteristics, specific for the genotypes, not allowing inference on a general and clear association between root-secreted phosphatase and dry matter production or $\mathrm{P}$ acquisition. Genotypic variability must be known and considered before using P-ase activity as an indicator of $\mathrm{P}$ nutritional status, or $\mathrm{P}$ tolerance, adaptation and efficiency under low $\mathrm{P}$ conditions.

Key words: Zea mays L., genetic variability, enzymatic activity, nutritional efficiency
\end{abstract}

\section{ATIVIDADE DE FOSFATASE ÁCIDA DE RAÍZES, CRESCIMENTO DAS PLANTAS E ACÚMULO DE FÓSFORO EM GENÓTIPOS DE MILHO}

\begin{abstract}
RESUMO: A atividade da enzima fosfatase é uma característica fisiológica relacionada à eficiência de aquisição e utilização de P pelas plantas e apresenta variação genotípica. Como parte de um estudo de caracterização de genótipos de milho quanto a características relacionadas à eficiência a fósforo, foram realizados dois experimentos para medir a atividade da fosfatase ácida de raízes intactas de seis variedades locais e melhoradas e de duas subpopulações. As plantas foram cultivadas em solução nutritiva com uma dose de $\mathrm{P}\left(4 \mathrm{mg} \mathrm{L}^{-1}\right)$ e a determinação da atividade da fosfatase foi feita em plantas jovens de 17 a 24 dias de idade. A produção de massa seca da parte aérea e raízes, teor e conteúdo de $\mathrm{P}$ e índice de eficiência de utilização de $\mathrm{P}$ também foram determinados. Entre as variedades, a maior atividade enzimática foi verificada em Catetão e Caiano (locais), e Sol da Manhã, Nitrodente e BR 106 (melhoradas). A variedade local Carioca foi a de menor atividade da fosfatase nas raízes. Entre as subpopulações, 'ND' foi menos produtiva e menos eficiente na utilização de $\mathrm{P}$, apresentando maior atividade enzimática que ' $\mathrm{ND}_{10}^{2}$ ', mais produtiva e eficiente. As atividades enzimáticas das subpopulações foram inferiores às das variedades. Foram obtidas correlações entre a atividade enzimática e as demais características, específicas para os genótipos, não permitindo deduzir a existência de associação consistente entre acumulação de massa e aquisição de $\mathrm{P}$ com a fosfatase secretada pelas raízes. A variabilidade genotípica deve ser conhecida e considerada antes de se definir a atividade desta enzima como indicador do estado nutricional de $\mathrm{P}$ e da tolerância, adaptação e eficiência das plantas em condições de baixo $P$.

Palavras-chave: Zea mays L., variabilidade genética, atividade enzimática, eficiência nutricional
\end{abstract}

\section{INTRODUCTION}

Phosphatases (P-ases), classified either as acid or alkaline, constitute an enzyme group which is presumed to catalyze the hydrolysis of several organic phosphate- monoesters, liberating available $\mathrm{Pi}$, and occurring scattered in all tissue cells of plant organs (Juma \& Tabatabai, 1988). Root-secreted phosphatase activity, named extracellular, is related to plant ability to make soil $\mathrm{P}$ available for absorption. The intracellular acid phosphatases, 
present in the cytosol, plastids and vacuoles, are responsible for the P-hydrolysis from organic compounds, favoring $\mathrm{P}$ mobilization and translocation from senescent tissues (Lee, 1988; Lefebvre et al., 1990; Duff et al., 1994). Therefore, this enzyme activity is a physiological characteristic related to plant efficiency in relation to $\mathrm{P}$ acquisition and utilization, and is genetically variable (Tadano et al., 1993). Plants usually secrete root acid Pases when $\mathrm{P}$ availability is low; however, plant species differ in secretion ability and enzyme activity (Duff et al., 1994; Fukuda et al., 2001; Yan et al., 2001).

It has been suggested that lower root or leaf acid $\mathrm{P}$-ase activities would be related to adequate or sufficient P-tissue concentrations, even under low external $\mathrm{P}$, when compared to high P-ase activity plants under the same conditions (Mc Lachlan, 1980a; 1980b; Silberbush et al., 1981; Furlani et al., 1984; Helal, 1990; Tadano et al., 1993). Such low P-ase activity plants would be potentially adapted to low-P environments, which might be explained by a lower plant demand for $\mathrm{P}$ and a feedback regulation effect on enzyme activity (Mc Lachlan \& De Marco, 1982). Therefore, plants adapted to lower external $P$ concentrations would have tissues adequately supplied in $\mathrm{P}$ and the lower P demand would inhibit P-ase activity.

Tadano et al. (1993) demonstrated differential interspecific genetic variability for root secretion and acid P-ase activity for nine plant species, among them, rice, wheat, tomato and lupin, and observed also different magnitudes in root enzyme activity increases in response to P deficiency. Mc Lachlan (1980a; 1980b) found variations in intact root enzyme activity among cultivated wheat species and their wild progenies. The cultivated species presented lower enzyme activities as compared to the wild, suggesting that selection for wheat plants more adapted to low $\mathrm{P}$ conditions might have occurred unconsciously. Furlani et al. (1984), investigating sorghum genotypes, and Helal (1990), working with common beans, observed large differences among tolerant and susceptible cultivars to low external $\mathrm{P}$ concentrations, and that the tolerant ones presented lower P-ase activities.

Intraspecific differences in root acid P-ase activities were observed among maize hybrids, related also to plant cycle (Kummerová \& Buresová, 1990), and among inbred lines (Clark \& Brown, 1974). The effects of the P-deficiency degree on the leaf P-ase activity in this species was also described by Elliott \& Läuchli (1986) and Kummerová (1986).

To identify differences in intact root acid phosphatase activity of maize plants, this research was carried out using six open-pollinated variety populations and two subpopulations obtained from the Nitrodente variety, correlating the enzyme activity with plant characteristics related to dry matter yield and efficiency of P uptake and utilization.

\section{MATERIAL AND METHODS}

\section{Plant material and experimental design}

Two experiments were carried out in greenhouse and growth chamber, at Campinas, SP, Brazil, using maize varieties and subpopulations from a field tested population. Both experiments followed a randomized complete block design with six replicates. Treatments consisted of six maize varieties and two contrasting subpopulations for the P-efficiency characters previously evaluated, that is, dry matter and grain yields, and Pefficiency utilization indexes (Machado, 2000; Machado et al., 2001). For the first experiment, an interpopulation study, three local ('Caiano de Sobrália', 'Carioca' and 'Catetão') and three improved varieties ('Nitrodente', 'Sol da Manhã', 'BR 106') were used. For the intrapopulation study, two subpopulations were formed by $S_{1}$ inbred-line families obtained from the Nitrodente variety, as follows: 200 inbred-line families were evaluated and classified for grain yield in a competition field trial (Machado, 2000); these families were grouped into ten groups of 20 families (corresponding to $10 \%$ of the total families), according to their increasing grain yield. From each group of the 20 families, the four highest and four lowest yielding families were excluded, and the twelve intermediary ones had their seeds mixed up, forming one group. Thus, ten representative groups were formed and constituted the subpopulations, codified as $\mathrm{ND}_{1}, \mathrm{ND}_{2}, \ldots$ up to $\mathrm{ND}_{10}$, ordered according to increasing grain yield. These ten subpopulations were evaluated in relation to the $\mathrm{P}$ uptake and utilization efficiency in nutrient solution (Machado et al., 2001; Machado \& Furlani, 2004), and two of them were used in the present research, $\mathrm{ND}_{2}$ and $\mathrm{ND}_{10}$, as contrasting subpopulations in relation to grain yield and P-utilization efficiency.

\section{Handling of plants and nutrient solutions}

Seeds were treated with fungicide and set for germination on paper rolls partly immersed in distilled water, under aeration. Seven day-old seedlings were transferred to 3.0-L plastic pots with lids, containing nutrient solution. Three uniform-sized seedlings were left per pot, suspended in the nutrient solution. The basic nutrient solution described by Furlani \& Furlani (1988), using p.a. reagents and deionized water, presented the following composition $\left(\mathrm{mg} \mathrm{L}^{-1}\right): \mathrm{Ca}=151 ; \mathrm{K}=141 ; \mathrm{Mg}=17 ; \mathrm{N}$ $\mathrm{NO}_{3}=138 ; \mathrm{N}^{-\mathrm{NH}_{4}}=20 ; \mathrm{S}=56 ; \mathrm{Cl}=33 ; \mathrm{Fe}=3.6 ; \mathrm{Mn}$ $=0.5 ; \mathrm{B}=0.27 ; \mathrm{Zn}=0.15 ; \mathrm{Cu}=0.04 ; \mathrm{Mo}=0.08$, as $\mathrm{Ca}\left(\mathrm{NO}_{3}\right)_{2} \cdot 4 \mathrm{H}_{2} \mathrm{O} ; \mathrm{NH}_{4} \mathrm{NO}_{3} ; \mathrm{KCl} ; \mathrm{K}_{2} \mathrm{SO}_{4} ; \mathrm{KNO}_{3}$; $\mathrm{MgSO}_{4} .7 \mathrm{H}_{2} \mathrm{O} ; \mathrm{Fe}$-EDTA (prepared with HEDTA and $\left.\mathrm{FeSO}_{4} \cdot 7 \mathrm{H}_{2} \mathrm{O}\right) ; \mathrm{MnCl}_{2} \cdot 4 \mathrm{H}_{2} \mathrm{O} ; \mathrm{H}_{3} \mathrm{BO}_{3} ; \mathrm{ZnSO}_{4} \cdot 7 \mathrm{H}_{2} \mathrm{O}$; $\mathrm{CuSO}_{4} \cdot 5 \mathrm{H}_{2} \mathrm{O}$ and $\mathrm{Na}_{2} \mathrm{MoO}_{4} \cdot 2 \mathrm{H}_{2} \mathrm{O}$, respectively. Phosphorus was added as $\mathrm{KH}_{2} \mathrm{PO}_{4}$, at one rate of $4 \mathrm{mg} \mathrm{L}^{-1}$ (12 mg P pot ${ }^{-1}$ ). 
The initial nutrient solution $\mathrm{pH}$ was adjusted to 5.2 and monitored each other day, not having been changed. Aeration and the level of water were kept constant. During the period of plant growth (January to February 1997), the daily maximum and minimum temperatures were recorded in the greenhouse: $36 \pm 6^{\circ} \mathrm{C}$ (day) and $24 \pm 1^{\circ} \mathrm{C}$ (night). The second experiment, using ' $\mathrm{ND}_{2}$ ' and ' $\mathrm{ND}_{10}$ ' subpopulations, was carried out in a growth-chamber because of the relatively low external temperatures at the time plants were grown (May 1997). In the growth-chamber, the average daily maximum and minimum temperatures were, respectively: $30 \pm 1{ }^{\circ} \mathrm{C}$ and $21 \pm 1{ }^{\circ} \mathrm{C}$. The photosynthetically active radiation given by the photosynthetic photon flux (FFF) was $200 \mu \mathrm{mol} \mathrm{m} \mathrm{m}^{-2} \mathrm{~s}^{-1}$.

\section{Intact root acid phosphatase activity essay}

Seventeen-day-old plants of six maize varieties (ten days in nutrient solution) from the first experiment were transferred to the growth-chamber in pots filled with aerated distilled water, where they were maintained during the night (12 hours). Twenty four day-old plants of the two maize subpopulations (' $\mathrm{ND}_{2}$ ' and ' $\mathrm{ND}_{10}$ ') from the second experiment, followed the same procedure. After this period in distilled water the determination of phosphatase activity in intact roots followed the same procedure: plants were transferred again to beakers (wrapped in aluminum foil) containing $500 \mathrm{~mL}$ of a 0.2 -strength nutrient solution with the enzyme substrate $-74.2 \mathrm{mg} \mathrm{mL}^{-1}$ of p-NPP (p-nitrophenilphosphate), $\mathrm{pH}$ adjusted to 4.0. Aliquots of $3 \mathrm{~mL}$ were taken at 15 and 30 minutes after plants were put in solutions with the substrate. The aliquots were transferred to test tubes containing $2 \mathrm{~mL}$ of $2 \mathrm{~mol} \mathrm{~L}^{-1} \mathrm{NaOH}$ solution according to the procedure described by Clark (1975). The p-nitrophenol formed turns yellow in a base solution. A control was run without plants, submitted to the same conditions, sampled at the same time, in order to evaluate the expontaneous substrate hydrolysis in the nutrient solution. The average temperature in the growth chamber during intact root $\mathrm{P}$-ase activity tests was $36^{\circ} \mathrm{C}$ in the first experiment with maize varieties; and $25^{\circ} \mathrm{C}$ in the second experiment with maize subpopulations; the photosynthetically active radiation $\left(\right.$ FFF $=200 \mu \mathrm{mol} \mathrm{m}^{-2} \mathrm{~s}^{-1}$ ) was the same in both experiments.

Intact root P-ase activity was related to the quantity of p-nitrophenol formed during the 15-minute interval (spectrophotometrical readings at $420 \mathrm{~nm}$ ), using standard p-nitrophenol solutions as reference for each set of readings. Control (without plants) readings were subtracted from the plant sample readings and P-ase activity was expressed as $\mathrm{mg} \mathrm{p}-\mathrm{NP} \mathrm{h}^{-1} \mathrm{~g}^{-1}$ root dry matter.

After P-ase activity measurements, plants were harvested, rinsed in distilled water and separated into shoots and roots. After this, plant parts were dried in a forced air oven at $70^{\circ} \mathrm{C}$ for dry matter determination, and then ground in a Willey-type grinder, following chemical analyses for the determination of tissue $\mathrm{P}$ concentrations by the ammonium vanado-molibdate method.

Plant P-utilization efficiency was evaluated by the efficiency index (E.I.) according to Siddiqi \& Glass (1981), based on dry matter yield (MS) related to the P concentration in the respective plant part tissues, that is, for the whole plant, IE $=(\text { total-MS })^{2} /$ total plant P-content. Experimental data were submitted to analyses of variance, and mean comparisons were made using Duncan's test either at $\alpha=0.05$ or $\alpha=0.01$.

\section{RESULTS AND DISCUSSION}

Maize varieties differed significantly in relation to the intact root phosphatase (P-ase) activities. 'Catetão', 'Caiano', 'Sol da Manhã', 'Nitrodente' and 'BR 106' presented higher values for P-ase activities (Table 1). 'Carioca' had the lowest root P-ase activity. No significant contrasts were observed between the two groups, local and improved varieties, and the average P-ase activity value was about the same for both groups, 38.83 and $38.73 \mathrm{mg} \mathrm{p}-\mathrm{NP} \mathrm{g}^{-1} \mathrm{~h}^{-1}$, respectively. No differences among varieties were observed within the improved group, but differences were found among the local ones, and ' $\mathrm{Ca}$ rioca' presented the lowest P-ase activity (Table 1).

Table 1 - Intact root acid phosphatase activity in maize genotypes. Average of six replications, three plants per pot. Values expressed per unit root dry matter.

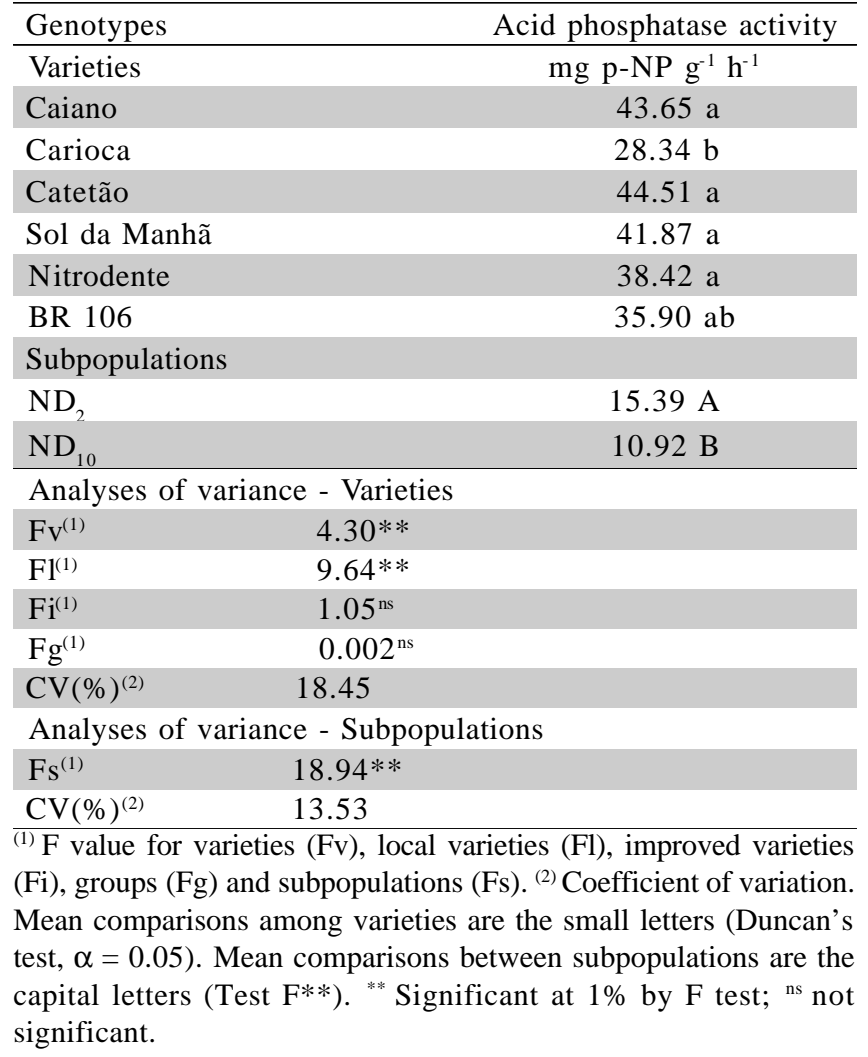


Although the method proposed by Clark (1975) refers to the determination of root P-ase activity in young plants, it might be supposed that the period of time (ten days) that plants were in nutrient solution in the first experiment with varieties was too short to cause a significant internal tissue P-stress and it did not allow the differentiation of varieties. However, the $\mathrm{P}$ concentration used in the nutrient solution, $4 \mathrm{mg} \mathrm{L}^{-1}$, was the intermediary level used in previous experiments with young plants of the same genotypes (Machado, 2000; Machado et al., 2001), and the values for root P-ase activity found for some varieties are very close to the ones reported by Clark (1975) for maize plants of same age. This author observed, however, maximum root enzyme activities in 21 day-old plants, as compared to older or younger plants, and considering a $\mathrm{P}$ concentration of $4 \mathrm{mg} \mathrm{L}^{-1}$, the limit above which the nutrient would be stored in the vacuoles and the P-ase activities would decrease significantly, when differences among genotypes for this character could no longer be detected. Nevertheless, plant responses (varieties and subpopulations) obtained in previous experiments, presented linear increases in dry matter yield up to $8 \mathrm{mg} \mathrm{L}^{-1}$, from what it was inferred that this $\mathrm{P}$ concentration $\left(4 \mathrm{mg} \mathrm{L}^{-1}\right)$ in the nutrient solution was expected to provide a significant $\mathrm{P}$-stress pressure on the plants.

There were differences between the ' $\mathrm{ND}_{2}$ ' and ' $\mathrm{ND}_{10}$ ' groups for the root $\mathrm{P}$-ase activities, and ' $\mathrm{ND}_{2}$ ', the lowest yielding subpopulation, presented higher P-ase activity as compared to ' $\mathrm{ND}_{10}$ ', the highest yielding one (Table 1). Enzyme activity values obtained in roots of the subpopulations were lower than those of the varieties, certainly because of the lower average temperature $\left(25^{\circ} \mathrm{C}\right)$ during the second experiment, as compared to temperature during the first $\left(36^{\circ} \mathrm{C}\right)$, although plants from the subpopulations were 24 day-old, the optimum age to reach maximum P-ase activity. These values were also lower than those found by Clark (1975) for plants of the same age. In this case, the effect of temperature on enzyme activity seemed to prevail on the root age effect, since the 24 day-old roots of ' $\mathrm{ND}_{2}$ ' and ' $\mathrm{ND}_{10}$ ' had $66 \%$ lower enzyme activity as compared to the 17 day-old roots of varieties. Clark (1975) observed that root P-ase activity increase as a function of temperature up to $30^{\circ} \mathrm{C}$, remaining steady between 30 and $40^{\circ} \mathrm{C}$, and increasing again around $50^{\circ} \mathrm{C}$, probably due to cell structure ruptures and enzyme release to the external solution, under these high temperatures. This author also observed a 50\% decrease in maize root $\mathrm{P}$-ase activity when temperature decreased from $35^{\circ} \mathrm{C}$ to $25^{\circ} \mathrm{C}$, an explanation for the differences found between plants from the first and second experiments.

In relation to variety dry matter yield of shoot and root, highest and lowest values were observed for the improved 'BR 106' and 'Sol da Manhã', respectively. No differences among local and improved variety groups were found for dry matter yield of plant parts or whole plants. Within the group of improved varieties, there were some significant contrasts between genotypes, with evidence to 'BR 106' with the highest values for shoot and root dry matter yield (Table 2). No variation on root/shoot ratio of dry matter were observed between or within groups of varieties. However, the best dry matter yielding varieties ('BR 106', 'Nitrodente' and 'Catetão') tended to accumulate more dry matter on shoots rather than on roots (Table 2). Between subpopulations, ' $\mathrm{ND}_{10}$ ' presented the highest values for shoot and root dry matter yield. No differences were observed between the two subpopulations for root/shoot ratios of dry matter yield (Table 2).

In relation to plant tissue $\mathrm{P}$ concentrations, differences were observed among varieties only for shoot P. 'Sol da Manhã' and 'BR 106' presented the highest and lowest shoot $\mathrm{P}$ concentrations, respectively; 'Carioca' presented the second highest shoot $\mathrm{P}$ concentration (Table 3). Local and improved varieties neither showed differ-

Table 2 - Dry matter yield of plant parts (shoot, root, whole plant) and root/shoot ratio of dry matter of maize genotypes. Average of six replications, three plants per pot.

\begin{tabular}{|c|c|c|c|c|}
\hline \multirow[b]{2}{*}{ Genotypes } & \multicolumn{3}{|c|}{ Dry matter yield } & \multirow{2}{*}{$\begin{array}{c}\text { Root/shoot } \\
\text { ratio }\end{array}$} \\
\hline & Shoots & Roots & Total & \\
\hline Varieties & \multicolumn{4}{|c|}{ - } \\
\hline Caiano & $1.14^{\mathrm{bc}}$ & $0.36^{\mathrm{b}}$ & $1.50^{\mathrm{bc}}$ & 0.37 \\
\hline Carioca & $1.00^{\mathrm{bc}}$ & $0.32^{\mathrm{bc}}$ & $1.32^{\mathrm{bc}}$ & 0.34 \\
\hline Catetão & $1.21^{\mathrm{b}}$ & $0.34^{\mathrm{bc}}$ & $1.55^{\mathrm{b}}$ & 0.29 \\
\hline Sol da Manhã & $0.80^{c}$ & $0.28^{c}$ & $1.08^{\mathrm{c}}$ & 0.36 \\
\hline Nitrodente & $1.28^{\mathrm{b}}$ & $0.36^{\mathrm{b}}$ & $1.64^{\mathrm{b}}$ & 0.28 \\
\hline BR 106 & $1.65^{\mathrm{a}}$ & $0.46^{\mathrm{a}}$ & $2.11^{\mathrm{a}}$ & 0.28 \\
\hline \multicolumn{5}{|l|}{ Subpopulations } \\
\hline $\mathrm{ND}_{2}$ & $1.00^{\mathrm{B}}$ & $0.18^{\mathrm{B}}$ & $1.18^{\mathrm{B}}$ & 0.16 \\
\hline $\mathrm{ND}_{10}$ & $3.95^{\mathrm{A}}$ & $0.65^{\mathrm{A}}$ & $4.60^{\mathrm{A}}$ & 0.16 \\
\hline \multicolumn{5}{|c|}{ Analyses of variance - Varieties } \\
\hline $\mathrm{Fv}^{(1)}$ & $5.62^{* *}$ & $5.71^{* *}$ & $6.06^{* *}$ & $1.41^{\mathrm{ns}}$ \\
\hline $\mathrm{Fl}^{(1)}$ & $0.74^{\mathrm{ns}}$ & $0.88^{\mathrm{ns}}$ & $0.74^{\mathrm{ns}}$ & $1.50^{\mathrm{ns}}$ \\
\hline $\mathrm{Fm}^{(1)}$ & $12.49^{* *}$ & $12.25^{* *}$ & $13.50^{* *}$ & $1.50^{\mathrm{ns}}$ \\
\hline $\mathrm{Fg}^{(1)}$ & $1.69^{\mathrm{ns}}$ & $1.25^{\mathrm{ns}}$ & $1.80^{\mathrm{ns}}$ & $0.63^{\mathrm{ns}}$ \\
\hline $\mathrm{CV}(\%)^{(2)}$ & 25.17 & 17.49 & 22.47 & 27.20 \\
\hline \multicolumn{5}{|c|}{ Analyses of variance - Subpopulations } \\
\hline $\mathrm{Fs}^{(1)}$ & $288.01^{* *}$ & $177.19^{* *}$ & $307.12^{* *}$ & $0.02^{\mathrm{ns}}$ \\
\hline $\mathrm{CV}(\%)^{(2)}$ & 12.17 & 14.96 & 11.73 & 22.59 \\
\hline
\end{tabular}

${ }^{(1)} \mathrm{F}$ value for varieties $(\mathrm{Fv})$, local varieties $(\mathrm{Fl})$, improved varieties (Fi), groups (Fg) and subpopulations (Fs). ${ }^{(2)}$ Coefficient of variation. Mean comparisons among varieties are the small letters (Duncan's test, $\alpha=0.05$ ). Mean comparisons between subpopulations are the capital letters (Test $\mathrm{F}^{* *}$ ). ${ }^{* *}$ Significant at $1 \%$ by $\mathrm{F}$ test; ${ }^{\text {ns }}$ not significant. 
Table 3 - Phosphorus concentration and content in plant parts (shoot, root, total), shoot/ root ratio of P content (S/R), Putilization efficiency index (PUEI) in maize genotypes. Average of six replications, three plants per pot.

\begin{tabular}{|c|c|c|c|c|c|c|c|}
\hline \multirow{3}{*}{$\begin{array}{l}\text { Genotypes } \\
\text { Varieties }\end{array}$} & \multicolumn{2}{|c|}{$\mathrm{P}$ concentration } & \multicolumn{4}{|c|}{$\mathrm{P}$ content } & \multirow{3}{*}{$\begin{array}{l}\text { PUEI } \\
\mathrm{g}^{2} \mathrm{mg}^{-1}\end{array}$} \\
\hline & Shoots & Roots & Shoots & Roots & Total & $\mathrm{S} / \mathrm{R}$ & \\
\hline & \multicolumn{2}{|c|}{$\ldots-\ldots \mathrm{mg} \mathrm{g}^{-1} \ldots \ldots$} & \multicolumn{4}{|c|}{ - } & \\
\hline Caiano & $6.07^{\mathrm{bc}}$ & 1.29 & $6.62^{b}$ & 0.46 & $7.08^{b}$ & 16.19 & $0.32^{\mathrm{b}}$ \\
\hline Carioca & $6.99^{\mathrm{b}}$ & 1.80 & $6.55^{\mathrm{b}}$ & 0.55 & $7.10^{\mathrm{b}}$ & 14.84 & $0.25^{\mathrm{bc}}$ \\
\hline Catetão & $6.53^{\mathrm{bc}}$ & 1.21 & $7.83^{\mathrm{ab}}$ & 0.42 & $8.25^{\mathrm{ab}}$ & 20.06 & $0.29^{\mathrm{b}}$ \\
\hline Sol da Manhã & $8.93^{\mathrm{a}}$ & 1.24 & $7.09^{\mathrm{b}}$ & 0.34 & $7.43^{\mathrm{b}}$ & 21.27 & $0.16^{\mathrm{c}}$ \\
\hline Nitrodente & $6.12^{\mathrm{bc}}$ & 1.23 & $7.77^{\mathrm{ab}}$ & 0.42 & $8.19^{\mathrm{ab}}$ & 19.91 & $0.33^{\mathrm{b}}$ \\
\hline BR 106 & $5.53^{\mathrm{c}}$ & 0.96 & $9.09^{\mathrm{a}}$ & 0.44 & $9.54^{\mathrm{a}}$ & 20.78 & $0.47^{\mathrm{a}}$ \\
\hline \multicolumn{8}{|l|}{ Subpopulations } \\
\hline $\mathrm{ND}_{2}$ & $5.68^{\mathrm{A}}$ & 2.96 & $5.57^{\mathrm{B}}$ & $0.68^{\mathrm{B}}$ & $6.25^{\mathrm{B}}$ & 8.19 & $0.22^{\mathrm{B}}$ \\
\hline $\mathrm{ND}_{10}$ & $3.02^{\mathrm{B}}$ & 2.91 & $11.80^{\mathrm{A}}$ & $1.88^{\mathrm{A}}$ & $13.68^{\mathrm{A}}$ & 6.35 & $1.56^{\mathrm{A}}$ \\
\hline \multicolumn{8}{|c|}{ An. variance - Varieties } \\
\hline $\mathrm{Fv}^{(1)}$ & $12.59^{* *}$ & $1.66^{\mathrm{ns}}$ & $3.50^{*}$ & $1.35^{\mathrm{ns}}$ & $3.52^{*}$ & $1.23^{\mathrm{ns}}$ & $6.71^{* *}$ \\
\hline $\mathrm{Fl}^{(1)}$ & $1.84^{\mathrm{ns}}$ & $2.19^{\mathrm{ns}}$ & $1.97^{\mathrm{ns}}$ & $1.39^{\mathrm{ns}}$ & $1.78^{\mathrm{ns}}$ & $1.28^{\mathrm{ns}}$ & $0.74^{\mathrm{ns}}$ \\
\hline $\mathrm{Fm}^{(1)}$ & $28.91^{* *}$ & $0.56^{\mathrm{ns}}$ & $2.47^{\mathrm{ns}}$ & $0.84^{\mathrm{ns}}$ & $4.55^{*}$ & $0.08^{\mathrm{ns}}$ & $16.38^{* *}$ \\
\hline $\mathrm{Fg}^{(1)}$ & $1.44^{\mathrm{ns}}$ & $2.83^{\mathrm{ns}}$ & $8.61^{* *}$ & $2.32^{\mathrm{ns}}$ & $4.97^{*}$ & $3.42^{\mathrm{ns}}$ & $0.89^{\text {ns }}$ \\
\hline $\mathrm{CV}(\%)^{(2)}$ & 12.34 & 40.61 & 16.68 & 31.47 & 15.45 & 31.20 & 31.88 \\
\hline \multicolumn{8}{|c|}{ An. variance - Subpopulations } \\
\hline $\mathrm{Fs}^{(1)}$ & $41.22^{* *}$ & $0.005^{\mathrm{ns}}$ & $70.80^{* *}$ & $24.28^{* *}$ & $58.89^{* *}$ & $4.46^{\mathrm{ns}}$ & $95.70^{* *}$ \\
\hline $\mathrm{CV}(\%)^{(2)}$ & 16.52 & 39.75 & 14.78 & 32.96 & 16.70 & 84.63 & 26.56 \\
\hline
\end{tabular}

${ }^{(1)} \mathrm{F}$ value for varieties $(\mathrm{Fv})$, for local varieties $(\mathrm{Fl})$, for improved varieties $(\mathrm{Fi})$, for groups $(\mathrm{Fg})$ and for subpopulations $(\mathrm{Fs}) .{ }^{(2)} \mathrm{Coefficient}$ of variation. Mean comparisons among varieties are the small letters (Duncan's test, $\alpha=0.05$ ). Mean comparisons between subpopulations are the capital letters (Test $\mathrm{F}^{* *}$ ). ${ }^{* *}$ Significant at 1\%; ${ }^{*}$ significant at 5\%; ${ }^{\text {ns }}$ not significant.

ences in $\mathrm{P}$ concentrations between shoots and roots nor between the variety groups. Among the improved, there was a clear differentiation for shoot $\mathrm{P}$ concentrations. The lowest or highest shoot $\mathrm{P}$ concentration was inversely related to dry matter yield, thus, 'Sol da Manhã NF' presented the lowest dry matter yield and highest shoot $\mathrm{P}$ concentration, whereas 'BR 106' had the highest dry matter yield and the lowest shoot $\mathrm{P}$ concentration, evidencing a nutrient dilution which occurred as a consequence of 'BR 106' having faster plant growth.

P-contents in plant parts were different among varieties (Table 3). 'BR106', 'Catetão' and 'Nitrodente' accumulated higher quantities of $\mathrm{P}$ in the shoots and whole plants. Improved varieties, in average, accumulated more $\mathrm{P}$ in the shoots and whole plants than the local ones.

No differences among local or improved varieties were observed for shoot and root P contents. Among the improved, differences were observed for total P contents, evidencing 'Sol da Manhã' and 'BR 106' as having the lowest and highest total $\mathrm{P}$ contents, respectively. The shoot/root ratio of $\mathrm{P}$ contents were similar either within or between the variety groups (Table 3 ).

In the subpopulations, 'ND, shoot $\mathrm{P}$ concentrations were higher than in the ' $\mathrm{ND}_{10}$ ', (although the root $\mathrm{P}$ concentrations were similar) as a result of nutrient di- lution effect, since ' $\mathrm{ND}_{10}$ ' had higher dry matter yield. The $\mathrm{P}$ contents in plant parts and in the whole plants were higher for ' $\mathrm{ND}_{10}$ '. The shoot/root ratios of $\mathrm{P}$ contents were not different between the two subpopulations, indicating similar P partition by both plant parts. These results are in agreement with the previous results obtained with the same maize local and improved varieties and subpopulations reported by Machado (2000) and Machado et al. (2001). These authors also observed similar results for dry matter and grain yield, root/shoot ratios of dry matter, Pconcentrations and P-contents in plant parts, mainly for the contrasting subpopulations $\mathrm{ND}_{2}$ and $\mathrm{ND}_{10}$ selected from the 'Nitrodente', which also presented significant differences for intact root $\mathrm{P}$-ase activities, evidencing their potential genetic variability for P-uptake and utilization.

According to the P-utilization efficiency indexes calculated, 'BR 106' was the most efficient, followed by the 'Nitrodente', 'Caiano', 'Catetão', 'Carioca' and 'Sol da Manhã' (Table 3). There were no differences in these P-efficiency indexes between the two groups, local and improved varieties, probably because treatments were applied for too short periods, which was also noticed for some of the other evaluated variables, mainly root P-ase activity. In a previous work, the improved varieties, evalu- 
ated at 25 days of age, presented higher values for the Pefficiency indexes as compared to the local ones (Machado, 2000; Machado et al., 2001). Within the group of improved varieties, 'BR 106' was the most efficient and 'Sol da Manhã', the most inefficient, presenting different P-utilization efficiency indexes. The subpopulations had contrasting values for the indexes, evidencing ' $\mathrm{ND}_{10}$ ' as the most efficient in P-utilization (Table 3), corroborating the previous results (Machado, 2000), although the present data consisted of lower absolute values.

Linear correlation coefficients (r) were calculated between intact root P-ase activity and the other characteristics (Table 4). For the maize local and improved varieties, there was no clear correlation between enzyme activity and the variables related to plant $P$ uptake and use efficiency. 'Caiano' and 'Carioca' presented correlation between P-ase activity and several P-efficiency variables, but this did not occur for the other varieties. In addition, for the existing correlations, the variables were not always the same, or even, sometimes directly or inversely correlated. For instance, only 'Caiano' and 'BR 106' had negative correlation coefficients between $\mathrm{P}$-ase activity and shoot $\mathrm{P}$-content $\left(-0.73^{+}\right)$or total-P content $\left(-0.73^{+}\right)$; 'Caiano' also presented negative correlation coefficients for shoot/root ratio of P-content $\left(-0.70^{+}\right)$, dry matter yields of shoots $\left(-0.73^{+}\right)$and whole plant $\left(-0.72^{+}\right)$. 'Caiano' and 'BR 106' behaved according to the initial hypothesis of $\mathrm{P}$-ase activity and nutritional P-status of the plants, that is, a negative relationship of $\mathrm{P}$-ase activity and the plant P-efficiency characters as expected. On the other hand, 'Carioca' had a negative correlation for root $\mathrm{P}$ concentration $(-0.82 *)$, but a positive correlation with shoot $\left(0.84^{*}\right)$ and total $\mathrm{P}$-content $\left(0.77^{+}\right)$, and shoot/root ratio of P-content $\left(0.84^{*}\right)$. 'Catetão' had a positive correlation for only one variable, root dry matter $\left(0.86^{*}\right)$. For the other two varieties (Sol da Manhã and Nitrodente) no correlations were found, indicating an inconsistent behaviour among local and improved varieties with relation to $\mathrm{P}$ ase activity and P-efficiency characters. The subpopulations $\mathrm{ND}_{2}$ and $\mathrm{ND}_{10}$ of Nitrodente had positive correlations only for one variable, the shoot/root ratio of P-content $\left(0.78^{+}\right.$and $\left.0.76^{+}\right)$, although the absolute values of $\mathrm{P}$ ase activities were different between the two inbred families, indicating a lower enzyme activity for the high yielding ' $\mathrm{ND}_{10}$ ' and a higher activity for the low yielding ' $\mathrm{ND}_{2}$ ' as it was expected (Table 4).

However, positive as well as negative correlations have been demonstrated between leaf or root enzyme activity and P content in plants (Besford, 1978; 1979; 1980; Mc Lachlan \& De Marco, 1982; Dracup et al., 1984; Elliot \& Läuchli, 1986; Fernandez \& Ascencio, 1994), or between P-ase activity and tolerance or susceptibility to P deficiency (Mc Lachlan 1980b; Silberbush et al., 1981; Furlani et al., 1984; Helal, 1990; Tadano et al., 1993). Nevertheless, the comparison of results is difficult because of the lack of sistematization and standardization of methods and criteria for the plant P-ase activity determination, in such way that, data of the literature are inconsistent or contradictory in relation to different species, different laboratory techniques and different plant part samples.

There are two prevailing hypotheses about the role of acid phosphatases in plants and its relationship with plant nutritional $\mathrm{P}$ status, as follows: (1) plants adapted to low $\mathrm{P}$ conditions (efficient in $\mathrm{P}$ uptake and utilization) would present high leaf or root P-ase activity as a sign of the ability in hydrolyzing and remobilizing $\mathrm{P}$, by root secretion and/or leaf synthesis, making $\mathrm{P}$ more

Table 4 - Correlation coefficients (r) between root acid phosphatase activity and the maize genotype P-efficiency characters.

\begin{tabular}{lcccccccc}
\hline \multirow{2}{*}{ Variables } & \multicolumn{3}{c}{ Varieties } & \multicolumn{3}{c}{ Subpopulations } \\
\cline { 2 - 8 } & Caiano & Carioca & Catetão & Sol da Manhã & Nitrodente & BR 106 & ND $_{2}$ & ND $_{10}$ \\
\hline SDM ${ }^{(1)}$ & $-0.73^{+}$ & $0.66^{\text {ns }}$ & $0.33^{\text {ns }}$ & $0.47^{\text {ns }}$ & $-0.51^{\text {ns }}$ & $-0.30^{\text {ns }}$ & $-0.53^{\text {ns }}$ & $-0.16^{\text {ns }}$ \\
RDM & $-0.64^{\text {ns }}$ & $0.50^{\text {ns }}$ & $0.86^{*}$ & $-0.60^{\text {ns }}$ & $-0.37^{\text {ns }}$ & $-0.58^{\text {ns }}$ & $-0.55^{\text {ns }}$ & $-0.06^{\text {ns }}$ \\
TDM & $-0.72^{+}$ & $0.64^{\text {ns }}$ & $0.45^{\text {ns }}$ & $0.06^{\text {ns }}$ & $-0.49^{\text {ns }}$ & $-0.38^{\text {ns }}$ & $-0.54^{\text {ns }}$ & $-0.15^{\text {ns }}$ \\
RDM/SDM & $0.63^{\text {ns }}$ & $-0.70^{\text {ns }}$ & $0.52^{\text {ns }}$ & $-0.68^{\text {ns }}$ & $0.03^{\text {ns }}$ & $-0.47^{\text {ns }}$ & $-0.64^{\text {ns }}$ & $0.27^{\text {ns }}$ \\
SP-conc & $0.68^{\text {ns }}$ & $-0.49^{\text {ns }}$ & $-0.51^{\text {ns }}$ & $-0.46^{\text {ns }}$ & $0.55^{\text {ns }}$ & $-0.49^{\text {ns }}$ & $0.25^{\text {ns }}$ & $0.00^{\text {ns }}$ \\
RP-conc & $0.67^{\text {ns }}$ & $-0.82^{*}$ & $0.40^{\text {ns }}$ & $0.41^{\text {ns }}$ & $0.32^{\text {ns }}$ & $-0.27^{\text {ns }}$ & $-0.63^{\text {ns }}$ & $-0.62^{\text {ns }}$ \\
SP-cont & $-0.73^{+}$ & $0.84^{*}$ & $-0.33^{\text {ns }}$ & $0.18^{\text {ns }}$ & $-0.34^{\text {ns }}$ & $-0.73^{+}$ & $-0.45^{\text {ns }}$ & $0.33^{\text {ns }}$ \\
RP-cont & $0.45^{\text {ns }}$ & $-0.65^{\text {ns }}$ & $0.59^{\text {ns }}$ & $-0.22^{\text {ns }}$ & $0.08^{\text {ns }}$ & $-0.58^{\text {ns }}$ & $-0.52^{\text {ns }}$ & $-0.68^{\text {ns }}$ \\
TP-cont & $-0.69^{\text {ns }}$ & $0.77^{+}$ & $-0.15^{\text {ns }}$ & $0.16^{\text {ns }}$ & $-0.35^{\text {ns }}$ & $-0.73^{+}$ & $-0.47^{\text {ns }}$ & $-0.34^{\text {ns }}$ \\
SP/RP & $-0.83^{*}$ & $0.84^{*}$ & $-0.64^{\text {ns }}$ & $0.36^{\text {ns }}$ & $-0.60^{\text {ns }}$ & $-0.16^{\text {ns }}$ & $0.78^{+}$ & $0.76^{+}$ \\
PUEI & $-0.70^{+}$ & $0.55^{\text {ns }}$ & $0.60^{\text {ns }}$ & $-0.12^{\text {ns }}$ & $-0.47^{\text {ns }}$ & $-0.10^{\text {ns }}$ & $-0.57^{\text {ns }}$ & $0.56^{\text {ns }}$ \\
\hline
\end{tabular}

${ }^{(1)} \mathrm{SDM}, \mathrm{RDM}$ and TDM $=$ shoot, root and total dry matter, respectively; RDM/SDM = root/shoot ratio of dry matter; SP-conc and $\mathrm{RP} \_$conc $=$shoot and root $\mathrm{P}$ concentration; SP-cont, RP-cont and TP-cont = shoot, root and total P content; SP/RP $=$ shoot $/$ root ratio of $\mathrm{P}$ content; PUEI $=$ P utilization efficiency index.

${ }^{+}, *$, **: significant, at 10,5 and $1 \%$ by Student's T test, respectively; ${ }^{\mathrm{ns}}$ not significant 
available to the plant, from soil or other older plant parts (Lee, 1988; Lefebvre et al., 1990; Barrett-Lenard et al., 1993); or (2) plants adapted to low P conditions (efficient in $\mathrm{P}$ uptake and utilization) would present a lower $\mathrm{P}$ demand and, consequently, a lower leaf or root P-ase activity under stress $\mathrm{P}$ conditions as compared to the nonadapted or higher $\mathrm{P}$ demanding plants. $\mathrm{P}$-ase activity would then be a chemical indicator of the plant $\mathrm{P}$ deficiency severity degree, and the more the plant is stressed in relation to $\mathrm{P}$, the higher the $\mathrm{P}$-ase activity and the less adapted the plant would be (Mc Lachlan 1980a; 1980b; Silberbush et al., 1981; Furlani et al., 1984; Elliot \& Läuchli, 1986; Helal, 1990; Tadano et al., 1993).

The first hypothesis anticipates a direct role of acid phosphatases on plant $\mathrm{P}$ uptake and use efficiency mechanisms, and the second assumes an indirect relationship, that is, an indication of a lower or higher P demand by the plants. It is impossible to conclude on any of the two above mentioned hypotheses, what might be credited to the fact of working with open-pollinated, high-variability genotypes like the local and improved varieties, and to the fact of working with very young plants, which might have been the case of the subpopulations, the results of which could not be confirmed by the correlation coefficients.

Clark \& Brown (1974) observed differences for intact root P-ase activity between two maize inbred lines, using young plants, and the highest activity inbred line presented also higher $\mathrm{P}$ content, that is, a direct relationship, indicating a better plant $\mathrm{P}$ nutritional status. In the present study, the variety having the highest $\mathrm{P}$ content had an intermediary P-ase activity, and the subpopulation with higher P content had lower P-ase activity.

Elliot \& Läuchli (1986) observed inverse relationship between plant $\mathrm{P}$ deficiency degree and leaf P-ase activity only for cases of severe P-deficiency. The enzyme activity was not useful to detect moderate to light $\mathrm{P}$ deficiency degrees. Variation in leaf P-ase activity relationship with $\mathrm{P}$ deficiency degree was also determined for maize plants, as a function of the leaf position in the plant (Kummerová, 1986). Variations derived from genetic differences were also observed by Kummerová \& Buresová (1990), when working with one early and one late maize hybrids, in the form of inverse relation between root dry matter yield and P-ase activity. The early hybrid presented lower root dry matter yield and higher enzyme activity, whereas the inverse was observed for the late one, high yielding and low enzyme activity.

For other plant species, the results are also quite inconsistent, and inverse relationships between P-ase activity and root $\mathrm{P}$ concentrations or contents have been found for sorghum (Furlani et al., 1984), white clover (Dracup et al., 1984), and common beans (Helal, 1990); between leaf and root P-ase activity and P deficiency in wheat plants (Mc Lachlan \& De Marco, 1982). On the other hand, Ascencio (1994) and Fernandez \& Ascencio (1994) did not observe any relationship between leaf or root P-ase activity and P deficiency in bean, cowpea, pigeon pea and cotton plants.

Consequently, such results are of difficult interpretation and comparison because P-ase activity data are derived from plants growing under different external $\mathrm{P}$ concentrations, or from different plant parts and/or from different genotypes, the origin of which might influence the gene expression of the acid phosphatase activity under a specific external $\mathrm{P}$ availability. Besides, the root ability to secrete acid phosphatases can only be evaluated when intact roots are used for the P-ase activity determination, and the secreted root P-ase activity may or may not be related to the plant $\mathrm{P}$ nutritional status, which is more easily demonstrated when leaves are also analyzed. Another complicating factor to be considered is that the gene control of acid P-ase synthesis and activation seems to be independent from the one that confers to the root the ability of enzyme secretion, which is usually activated under low P levels (Fukuda et al., 2001). Recently, Fukuda et al. (2001), Wasaki et al. (2001) and other researchers have investigated the possibility of gene transfer of the root character responsible for acid P-ase secretion, in order to obtain plants more efficient in making soil $\mathrm{P}$ available. However, the root secreted acid Pase activity gene expression should be related to a significant root P-uptake efficiency expression, in order to obtain an effective gain in P-uptake and utilization efficiency.

From the actual knowledge on the high variability existing within maize populations and genotypes as to their root ability in P-ase synthesis and secretion, and also on the independent gene control of such processes, it is not recommended using acid phosphatase activity as a physiological marker for evaluation of plants in relation to $\mathrm{P}$ uptake and utilization efficiency under low $\mathrm{P}$ conditions.

\section{ACKNOWLEDGEMENTS}

To FAPESP, CNPq and CAPES for financial support and grants.

\section{REFERENCES}

ASCENCIO, J. Acid phosphatase as a diagnostic tool. Communications in Soil Science and Plant Analysis, v.25, p.1553-1564, 1994

BARRETT-LENARD, E.G.; DRACUP, M.; GREENWAY, H. Role of extracellular phosphatases in the phosphorus-nutrition of clover. Journal of Experimental Botany, v.44, p.1595-1600, 1993.

BESFORD, R.T. Effect of phosphorus supply on acid phosphatase activity in the leaves of tomato plants. Scientia Horticulturae, v.9, p.303-309, 1978.

BESFORD, R.T. Phosphorus nutrition and acid phosphatase activity in the leaves of seven plant species. Journal of the Science and Food and Agriculture, v.30, p.281-285, 1979.

BESFORD, R.T. A rapid tissue test for diagnosing phosphorus deficiency in the tomato plants. Annals of Botany, v.45, p.225-227, 1980. 
CLARK, R.B. Characterization of phosphatase of intact maize roots. Journal of Agricultural and Food Chemistry, v.23, p.458-460, 1975.

CLARK, R.B.; BROWN, J.C. Differential phosphorus uptake by phosphorus - stressed corn inbreds. Crop Science, v.14, p.505-508, 1974.

DRACUP, M.N.H.; BARRETT-LENNARD, E.G.; GREENWAY, H.; ROBSON, A.D. Effect of phosphorus deficiency on phosphatase activity of cell walls from roots of subterranean clover. Journal of Experimental Botany, v.35, p.466-480, 1984.

DUFF, S.M.G.; SARATH, G.; PLAXTON, W.C. The role of acid phosphatase in plant phosphorus metabolism. Physiologia Plantarum, v.90, p.791-800, 1994.

ELLIOT, G.C.; LÄUCHLI, A. Evaluation of an acid phosphatase assay for detection of phosphorus deficiency in leaves of maize (Zea mays L.) Journal of Plant Nutrition, v.9, p.1469-1477, 1986.

FERNANDEZ, D.S.; ASCENCIO, J. Acid phosphatase activity in bean and cowpea plants grown under phosphorus stress. Journal of Plant Nutrition, v.17, p.229-241, 1994.

FUKUDA, T.; OSAKI, M.; SHINANO, T.; WASAKI, J. Cloning and characterization of two secreted acid phosphatases from rice calli. In: HORST, W.J.; SCHENK, M.K.; BÜRKERT, A.; CLAASSEN, N.; FLESSA, H.; FROMMER, W.B.; GOLDBACH, H.; OLFS, H.W.; RÖMHELD, V.; SATTELMACHER, B.; SCHMIDHALTER, U.; SCHUBERT, S.; WIRÉN, N.V.; WITTENMAYER, L. (Ed.) Plant nutrition: food security and sustainability of agro-ecosystems through basic and applied research. Dordrecht: Kluwer Academic, 2001. p.3435.

FURLANI, A.M.C.; FURLANI, P.R. Composição e pH de soluções nutritivas para estudos fisiológicos e seleção de plantas em condições nutricionais adversas. Campinas: Instituto Agronômico, 1988. 34p. (Boletim, 121).

FURLANI, A.M.C.; CLARK, R.B.; MARANVILLE, J.W.; ROSS, W.M. Root phosphatase activity of sorghum genotypes grown with organic and inorganic sources of phosphorus. Journal of Plant Nutrition, v.7, p.1583-1595, 1984.

HELAL, H.M. Varietal differences in root phosphatase activity as related to the utilization of organic phosphates. Plant and Soil, v.123, p.161163, 1990.

JUMA, N.G.; TABATABAI, M.A. Phosphatase activity in corn and soybean roots: conditions for assay and effects of metals. Plant and Soil, v.107, p.39-47, 1988.

KUMMEROVÁ, M. Acid phosphatase activity in maize leaves as related to their evolution and phosphorus deficiency. Biologia Plantarum, v.28, p.391-395, 1986.

KUMMEROVÁ, M.; BURESOVÁ, I. The effect of exogenous phosphate deficiency on the activity of acid phosphatase of the root of two maize genotypes. Biologia Plantarum, v.32, p.1-7, 1990.

LEE, R.B. Phosphate influx and extracellular phosphatase activity in barley roots and rose cells. New Phytologist, v.109, p.141-148, 1988.

LEFEBVRE, D.D.; DUFF, S.M.G.; FIFE, C.A.; JULIEN-INALSINGH, C.; PLAXTON, W.C. Response to phosphate deprivation in Brassica nigra suspension cells. Enhancement of intracellular cell surface, and secreted phosphatase activities compared to increases in Pi absorption rate. Plant Physiology, v.93, p.504-511, 1990.
MACHADO, C.T. de T. Caracterização de genótipos de milho (Zea mays L.) quanto aos parâmetros morfológicos, fisiológicos e microbiológicos associados à eficiência na absorção e utilização de fósforo. Seropédica: UFRRJ, 2000. 366p. (Tese - Doutorado).

MACHADO, C.T.de T.; FURLANI, A.M.C. Kinetics of phosphorus uptake and root morphology of local and improved varieties of maize. Scientia Agricola, v.61, p.69-76, 2004.

MACHADO, C.T.de T.; FURLANI, A.M.C.; MACHADO, A.T. Índices de eficiência de variedades locais e melhoradas de milho ao fósforo. Bragantia, v.60, p.225-238, 2001.

MC LACHLAN, K.D. Acid phosphatase activity of intact roots and phosphorus nutrition in plants: I. Assay conditions and phosphatase activity. Australian Journal of Agricultural Research, v.31, p.429440, 1980a.

MC LACHLAN, K.D. Acid phosphatase activity of intact roots and phosphorus nutrition in plants: II. Variations among wheat roots. Australian Journal of Agricultural Research, v.31, p.441-448, 1980b.

MC LACHLAN, K.D.; DE MARCO, D.G. Acid phosphatase activity of intact roots and phosphorus nutrition in plants: III. Its relation to phosphorus garnering by wheat and a comparison with leaf activity as a measure of phosphorus status. Australian Journal of Agricultural Research, v.33, p.1-11, 1982.

SIDDIQI, M.Y.; GLASS, A.D.M. Utilization index: A modified approach to the estimations and comparison of nutrient utilization efficiency in plants. Journal of Plant Nutrition, v.4, p.289-302, 1981.

SILBERBUSH, M.; SHOMER-ILAN, A.; WAISEL, Y. Root surface phosphatase activity in ecotypes of Aegilops peregrina. Physiologia Plantarum, v.53, p.501-504, 1981.

TADANO, T.; OZAWA, K.; SAKAI, H.; OSAKI, M.; MATSUI, H. Secretion of acid phosphatase by the roots of crop plants under phosphorusdeficient conditions and some properties of the enzyme secreted by lupin roots. Plant and Soil, v.155/156, p.95-98, 1993.

WASAKI, J.; DATEKI, H.; SHINANO, T.; OSAKI, M.; TADANO, T. Characterization of secretory acid phosphatase gene of lupin roots and the transformation of the gene into tobacco plants. In: HORST, W.J.; SCHENK, M.K.; BÜRKERT, A.; CLAASSEN, N.; FLESSA, H.; FROMMER, W.B.; GOLDBACH, H.; OLFS, H.W.; RÖMHELD, V.; SATTELMACHER, B.; SCHMIDHALTER, U.; SCHUBERT, S.; WIRÉN, N.V.; WITTENMAYER, L. (Ed.)Plant nutrition: food security and sustainability of agro-ecosystems through basic and applied research. Dordrecht: Kluwer Academic, 2001. p.36-37.

YAN, X.; LIAO, H.; TRULL, M.C.; BEEBE, S.E.; LYNCH, J.P. Induction of a major leaf acid phosphatase does not confer adaptation to low phosphorus availability in common bean. Plant Physiology, v.125, p.1901-1911, 2001.

Received November 18, 2002

Accepted January 28, 2004 